sphere storage. J. Food Qual. 17:477-494.

Brooks, C., J.S. Cooley, and D.F. Fisher. 1919. Nature and control of apple scald. J. Agr. Res. $18: 211-240$

Chen, P.M., R.A. Spotts, and W.M. Mellenthin. 1981. Stem-end decay and quality of low oxygen stored 'd'Anjou' pears. J. Amer. Soc. Hort. Sci. 106:522-527.

Chen, P.M. and D.M. Varga. 1989. 'Black speck', a superfical disorder of 'd'Anjou' pears after prolonged CA storage, p.145-156. In: J.K. Fellman (ed.). Controlled atmospheres for storage and transport of perishable agricultural commodities. 5th Intl. Controlled Atmosphere Research Conf.

Cooley, J.S. and J.H. Crenshaw. 1931. Control of botrytis rot of pears with chemically treated wrappers. USDA. Circ. 177.

Drake, S.R. 1994. Elevated carbon dioxide storage of 'Anjou' pears using purge-controlled atmosphere. HortScience 29:299-301.

Hansen, E. 1957. Reactions of Anjou pears to carbon dioxide and oxygen content of the storage atmosphere. Proc. Amer. Soc. Hort. Sci. 69:110115

Hansen, E. and W.M. Mellenthin. 1979. Commercial handling and storage practices for winter pears. Ore. State Univ. Agr. Expt. Sta. Rpt. 550.

Hardenburg, R.E.,A.E. Watada, and C.Y.Wang. 1986. The commercial storage of fruits, vegetables and florist and nursery stocks. U.S. Dept. Agr. Hdbk. 66

Hunter, R.S. and R.W. Harold. 1987. The measurement of appearance. 2nd ed. Wiley, New York.

Kupferman, E.M. 1988. Research on skin speckling and pithy brown core of 'd'Anjou' pears reported. Good Fruit Grower 39:17-18.

Lee, S.P., P.M. Chen, T.H.H. Chen, D.M. Varga, and E.A. Mielke. 1990. Differences of biochemical components between the skin tissues of normal and black-speckled 'd'Anjou' pears after prolonged low-oxygen storage. J. Amer. Soc. Hort. Sci. 115:784-788.

Meheriuk, M. 1993. CA storage conditions for apples, pears and nashi, p. 819-858. vol 2. In: Proc. 6th. Intl. Controlled Atmosphere Res. Conf., June 1993, Ithaca, N.Y.

Mellenthin, W.M., P.M. Chen, and S.B. Kelly. 1980. Low oxygen effects on dessert quality, scald prevention and nitrogen metabolism of 'd'Anjou' pear fruit during long term storage. J. Amer. Soc. Hort. Sci. 105:695-698.

Michigan State University. 1988. MSTATC,Version 1.0. East Lansing, Mich.

Washington Department of Agriculture. 1990 Washington controlled atmosphere storage requirements for winter pears. WAC 16-449-010 20 Sept. 1973. Wash. Dept. Agr., Olympia.

\section{Influence of Temperature Gradients on Triploid and Diploid Watermelon Seed Germination}

\author{
Richard L. Hassell, \\ Robert J. Dufault, and \\ Tyron L. Phillips
}

Additional IndeX words. Citrullus lanatus, thermogradient, vigor test, seed vigor, germination index

Summary. Ten triploid and 25 diploid watermelon (Citrullus lanatus) selections were evaluated to determine the temperature range and length of test for which germination index (rate of germination over time) and germination percentages were maximum for expediting vigor and seed testing practices. Temperature interacted with watermelon selection indicating that certain selections germinated faster within specific, but differing temperature ranges. Within 2 days after starting the germination process, $90 \%$ of triploid selections and $96 \%$ of diploid selections germinated to their greatest level and prolonging germination data collection for one week did not change this relationship. Although optimal temperature ranges may differ among the selections, the one temperature within the range common for all selections evaluated that maximized germination was 85 to $90{ }^{\circ} \mathrm{F}\left(29.4\right.$ to $\left.32.2^{\circ} \mathrm{C}\right)$ for diploids and $85{ }^{\circ} \mathrm{F}$ for triploids.

W atermelons are native to South Africa (Simmonds, 1976) and were introduced into Europe in the $16^{\text {th }}$ century and the United States in 1629 (Thompson

Department of Horticulture, Clemson University, Coastal Research and Education Center, Charleston, SC 29414.

The cost of publishing this paper was defrayed in part by payment of page charges. Under postal regulations, this paper therefore must be hereby marked as adver tisement solely to indicate this fact. and Kelly, 1957). Diploid watermelons require warm temperatures of $>79$ ${ }^{\circ} \mathrm{F}\left(26^{\circ} \mathrm{C}\right)$ for seed germination and proper growth and development (Whitaker and Davis, 1962). In the early 1950s, optimal soil temperatures for diploid seed germination were established that range from 70 to $95^{\circ} \mathrm{F}$ (21 to $35^{\circ} \mathrm{C}$ ) with $95^{\circ} \mathrm{F}$ as optimal and $59^{\circ} \mathrm{F}\left(15^{\circ} \mathrm{C}\right)$ and $104^{\circ} \mathrm{F}\left(40^{\circ} \mathrm{C}\right)$ considered the minimum and maximum temperatures, respectively (Harrington and Minges, 1954). Since then, new hybrid diploid cultivars have replaced the older open-pollinated cultivars and these new cultivars may respond to temperatures differently.

Triploid (seedless) watermelons were first developed in the early 1950s at Kyoto University in Japan (Kihara, 1951). Since their development, inferior seed germination has been a serious problem with triploids. The triploid seeds $(3 \times)$, originating from tetraploid ovaries $(4 \times)$, have hard, thick seed coats that interfere with germination (Kihara, 1951; Sachs, 1977). Triploid watermelon seed production is a complicated, expensive process (Marr et al., 1991), compared with diploid seed production. Because of high seed cost and reduced viability with triploid versus diploid watermelon seeds, growers use transplants from seeds that are germinated in temperature-controlled rooms to facilitate uniform germination and improved plant production. Even if triploid plants are produced in controlled environments, seedling emergence and growth may still be reduced with uneven germination and seedling emergence and poor seedling vigor and growth rate.

Presently, the temperature of germination rooms for triploid watermelons may range from 75 to $100^{\circ} \mathrm{F}(24$ to $38^{\circ} \mathrm{C}$ ) for 24 to $72 \mathrm{~h}$ depending on a transplant company's protocol. Vavrina and Maynard (1998) concluded that triploids germinate optimally between 84 to $90^{\circ} \mathrm{F}$ ( 29 to 32 ${ }^{\circ} \mathrm{C}$ ) for a 24 to $48 \mathrm{~h}$ period or until the radicles emerge from the seed coat. Given the fact that seedless watermelons are currently very popular with consumers, the major seed suppliers have released many new watermelon cultivars to meet those demands (Maynard and Elmstrom, 1992). It is unknown, however, if the general temperature range proposed by Vavrina and Maynard (1998) is appropriate for new triploid watermelons. Still, even 
under this suggested temperature regime, growers often have problems obtaining complete, uniform germination, and sometimes seedlings have abnormally long hypocotyls. In order to grow the most uniform, rapid-growing transplants, the optimum temperature range to germinate new triploid watermelons must be verified.

Although knowledge of the optimum relationship between temperature and final seed germination percentage of both diploid and triploid watermelons is important and beneficial to transplant growers, of equal value is information relating to vigor of a given seed lot. Seed vigor comprises those properties which determine the potential for rapid, uniform emergence, and the development of normal seedlings under a wide range of field or greenhouse conditions [Association of Official Seed Analysts (AOSA), 1983]. It is customary that seed companies provide final germination percentages on seed containers, but they do not provide an index of seed vigor. Knowledge of seed vigor, expressed as an index of how fast germination reaches its maximal rate over time at the optimum temperature for germination, would provide transplant growers valuable information to measure and compare the robustness of seed lots. Maguire (1962) developed a useful germination index formula that could easily convert simple germination percentage data taken over time into a measure of vigor: Germination index $=\sum$ (number of normal seedlings $) /$ (days to first count $)+\ldots .+$ (number of normal seedlings) $/$ (days to final count).

High seed germination vigor is critical for the efficient production of transplants and may be a strong indicator of field performance, especially for triploid watermelons.

The protocol to determine final seed germination percentage of watermelons is outlined by AOSA (1998). The recommended germination test procedure, described by AOSA, requires germination at $86^{\circ} \mathrm{F}\left(30^{\circ} \mathrm{C}\right)$ with first germination counts taken after $4 \mathrm{~d}$ and final counts taken on the $14 \mathrm{~d}$. This simple germination test, however, does not provide information on the actual seed vigor or rate of early emergence. Delaying the termination of germination test until $14 \mathrm{~d}$ pass for final germination percentage information is hypothesized to be excessive and, further, delaying first counts to $4 \mathrm{~d}$ is too late to judge seed vigor superiority. Since high-vigor seeds emerge earlier than low-vigor seeds, quick determination of seed vigor in a minimum amount of time would be beneficial to transplant growers as well as seed companies. A thermogradient test could be used to measure seed vigor as well as final germination percentages under a wide range of temperatures. The information provided from thermogradient tests can be easily converted into a germination index that relates germination percentage as a function of time.

The objective of this research was to determine for new triploid and diploid watermelon selections, the temperature range(s) and days from testing initiation for which watermelon germination index (germination rate over time) and germination percentages are maximized.

\section{Materials and methods}

Seeds of 10 triploid watermelon selections were evaluated: 'Summer Sweet 2532, 3521Y, and 5244' (Abbott and Cobb, Feasterville, Pa.); 'Marita' and 'Rubita' (United Genetics, Hollister, Calif.); 'Disko' (Hazera, El Segundo, Calif.); 'Treasure Chest', 'Triple Crown', 'Triple Prize', and 'Triple Star' (Seeds By Design, Willows, Calif.). Seeds of 25 diploid watermelon selections were evaluated: 'Summer Flavor 400, 500, 510, 700, $800,810,820,900,5451,7401$, and 7402' (Abbott and Cobb); 'Carnival' and 'RWM 8036-VP' (Syngenta, Boise, Idaho); 'Regency', 'Royal Flush', 'Royal Star', 'Royal Sweet' and 'Sentinel' (Petoseeds, Oxnard, Calif.); 'Verde Grande' (D. Palmer, Yuma, Ariz.); 'Mara' and 'Sanata Vittoria' (United Genetics); 'SWD 8307' (Sakata, Morgan Hill, Calif.); and 'Imperial', 'Majesty', and 'Royalty' (Seeds by Design). Upon delivery, the seeds were placed in a seed storage facility at $57^{\circ} \mathrm{F} \pm 3.6^{\circ} \mathrm{F}\left(13.8^{\circ} \mathrm{C} \pm 2^{\circ} \mathrm{C}\right)$ and $50 \%$ relative humidity until needed.

Four-hundred seeds of each watermelon selection were divided into eight groups of 50 seeds each, then each group was placed into transparent acrylic containers, lined on the bottom with blue germination blotter (Hoffman Manufacturing Co., Albany, Ore.) and moistened with distilled water. Transparent acrylic lids covered the containers to prevent moisture loss. These containers were placed along a temperature gradient on a thermogradient table, Type 5001 (Seed Processing Holland, Enkhuizen, The

Table 1. Influence of duration of thermogradient testing on seed germination index of triploid watermelon selections.

\begin{tabular}{|c|c|c|c|c|c|}
\hline \multirow{2}{*}{$\begin{array}{l}\text { Watermelon } \\
\text { selection }\end{array}$} & \multicolumn{5}{|c|}{$\begin{array}{l}\text { Time after initiation of } \\
\text { thermogradient testing (d) }\end{array}$} \\
\hline & 2 & 3 & 4 & 5 & 7 \\
\hline Disko & $10.3 \mathrm{a}^{\mathrm{y}}$ & $6.0 \mathrm{~b}$ & $1.1 \mathrm{c}$ & $0.6 \mathrm{c}$ & $0.1 \mathrm{c}$ \\
\hline Rubita & $5.7 \mathrm{a}$ & $3.6 \mathrm{~b}$ & $1.4 \mathrm{c}$ & $0.7 \mathrm{~d}$ & $0.4 \mathrm{~d}$ \\
\hline Marita & $0.9 \mathrm{ab}$ & $1.3 \mathrm{a}$ & $0.4 \mathrm{bc}$ & $0.2 \mathrm{c}$ & $0.1 \mathrm{c}$ \\
\hline Summer Sweet 2532 & $7.0 \mathrm{a}$ & $5.2 \mathrm{~b}$ & $2.0 \mathrm{c}$ & $0.8 \mathrm{~d}$ & $0.8 \mathrm{~d}$ \\
\hline Summer Sweet $3521 Y$ & $1.7 \mathrm{ab}$ & $2.1 \mathrm{a}$ & $1.3 \mathrm{~b}$ & $0.6 \mathrm{c}$ & $0.7 \mathrm{cb}$ \\
\hline Treasure Chest & $6.2 \mathrm{a}$ & $2.2 \mathrm{~b}$ & $0.6 \mathrm{c}$ & $0.5 \mathrm{c}$ & $0.4 \mathrm{c}$ \\
\hline Triple Crown & $11.0 \mathrm{a}$ & $3.9 \mathrm{~b}$ & $1.2 \mathrm{c}$ & $1.0 \mathrm{c}$ & $0.4 \mathrm{c}$ \\
\hline Triple Prize & $6.4 \mathrm{a}$ & $4.4 \mathrm{~b}$ & $1.1 \mathrm{c}$ & $0.6 \mathrm{c}$ & $0.9 \mathrm{c}$ \\
\hline Triple Star & $3.2 \mathrm{~b}$ & $4.7 \mathrm{a}$ & $1.6 \mathrm{c}$ & $0.9 \mathrm{~d}$ & $0.8 \mathrm{~d}$ \\
\hline
\end{tabular}

${ }^{\mathrm{z}}$ Germination index $=\sum$ (number of normal seedlings $) /($ days to first count $)+\ldots .+$ (number of normal seedlings $) /($ days to final count).

${ }^{y}$ Means within rows by LSD $(P=0.05)$. Data are means of three replications pooled over eight temperatures ranging from 62 to $94{ }^{\circ} \mathrm{F}$ ( 16.7 to $\left.34.4{ }^{\circ} \mathrm{C}\right)$. 
Table 2. Influence of temperature on seed germination percentage of triploid watermelon selections after 2 days on a thermogradient table.

\begin{tabular}{|c|c|c|c|c|c|c|c|c|c|}
\hline \multirow{2}{*}{$\begin{array}{l}\text { Watermelon } \\
\text { selection }\end{array}$} & \multicolumn{9}{|c|}{$\operatorname{Temp}\left({ }^{\circ} \mathbf{F}\right)^{\mathrm{z}}$} \\
\hline & 62 & 66 & 70 & 75 & 80 & 85 & 90 & 94 & Ideal range \\
\hline Disko & $0.0 \mathrm{e}^{\mathrm{y}}$ & $1.3 \mathrm{~d}$ & $26.7 \mathrm{c}$ & $30.0 \mathrm{c}$ & $88.0 \mathrm{a}$ & $88.7 \mathrm{a}$ & $75.3 \mathrm{~b}$ & $12.7 \mathrm{~d}$ & $80-85$ \\
\hline Triple Crown & $0.0 \mathrm{c}$ & $1.0 \mathrm{c}$ & $10.0 \mathrm{c}$ & $62.0 \mathrm{~b}$ & 78.7 a & 80.7 a & 80.7 a & $58.7 \mathrm{~b}$ & $80-90$ \\
\hline Triple Star & $0.0 \mathrm{~b}$ & $0.0 \mathrm{~b}$ & $1.3 \mathrm{~b}$ & $5.3 \mathrm{~b}$ & $21.3 \mathrm{ab}$ & $28.7 \mathrm{a}$ & $32.7 \mathrm{a}$ & $11.3 \mathrm{~b}$ & $80-90$ \\
\hline Triple Prize & $0.0 \mathrm{~d}$ & $0.0 \mathrm{~d}$ & $1.0 \mathrm{~d}$ & $26.7 \mathrm{c}$ & $40.0 \mathrm{~b}$ & $58.0 \mathrm{a}$ & $45.3 \mathrm{~b}$ & $33.3 \mathrm{bc}$ & 85 \\
\hline Summer Sweet 2532 & $0.0 \mathrm{~d}$ & $0.0 \mathrm{~d}$ & $1.0 \mathrm{~d}$ & $5.3 \mathrm{~d}$ & $46.0 \mathrm{~b}$ & $64.7 \mathrm{a}$ & $78.0 \mathrm{a}$ & $28.7 \mathrm{c}$ & $85-90$ \\
\hline Treasure Chest & $0.0 \mathrm{c}$ & $1.3 \mathrm{c}$ & $4.7 \mathrm{c}$ & $29.3 \mathrm{~b}$ & $36.0 \mathrm{~b}$ & $50.0 \mathrm{a}$ & $50.0 \mathrm{a}$ & $28.0 \mathrm{~b}$ & $85-90$ \\
\hline Marita & $0.0 \mathrm{a}$ & $0.0 \mathrm{a}$ & $0.0 \mathrm{a}$ & $1.0 \mathrm{a}$ & $2.7 \mathrm{a}$ & $12.0 \mathrm{a}$ & $8.0 \mathrm{a}$ & $4.0 \mathrm{a}$ & --- \\
\hline Summer Sweet 3521Y & $0.0 \mathrm{~b}$ & $0.0 \mathrm{~b}$ & $1.0 \mathrm{~b}$ & $1.3 \mathrm{~b}$ & $6.7 \mathrm{~b}$ & $17.3 \mathrm{a}$ & $20.0 \mathrm{a}$ & $7.3 \mathrm{~b}$ & --- \\
\hline
\end{tabular}

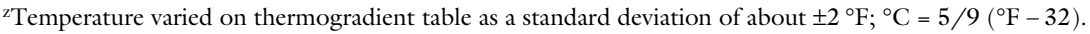

${ }^{y}$ Means within rows by LSD $(P=0.05)$. Data are means of three replications.

Netherlands), and allowed to germinate over a 7 -d period. The gradient treatments: $\left[ \pm 2{ }^{\circ} \mathrm{F}\left(+1.1^{\circ} \mathrm{C}\right)\right]$ were $62,66,70,75,80,85,90,94^{\circ} \mathrm{F}$, (16.7, 18.9, 21.1, 23.9, 26.7, 29.4, 32.2 , and $34.4^{\circ} \mathrm{C}$ ). Temperatures were measured within the containers using a 12-channel scanning thermocouple thermometer (Barnant Co.,
Barrington, Ill. ). Containers representing each watermelon selection were randomly arranged within temperature treatment locations on the thermogradient table.

The experiment was a factorial combination of selection, temperature, and day of germination counts. The experiment was replicated three times with a replicate equal to repeating the entire experiment with seeds from the same lots on three different occasions over a 6-week period. Triploid and diploid tests were done in separate experiments. Germination counts were taken at the same time daily for $7 \mathrm{~d}$. A seed was considered germinated, and would ultimately produce a usable

Table 3. Influence of duration of thermogradient testing on seed germination index of diploid watermelon selections and experimental lines.

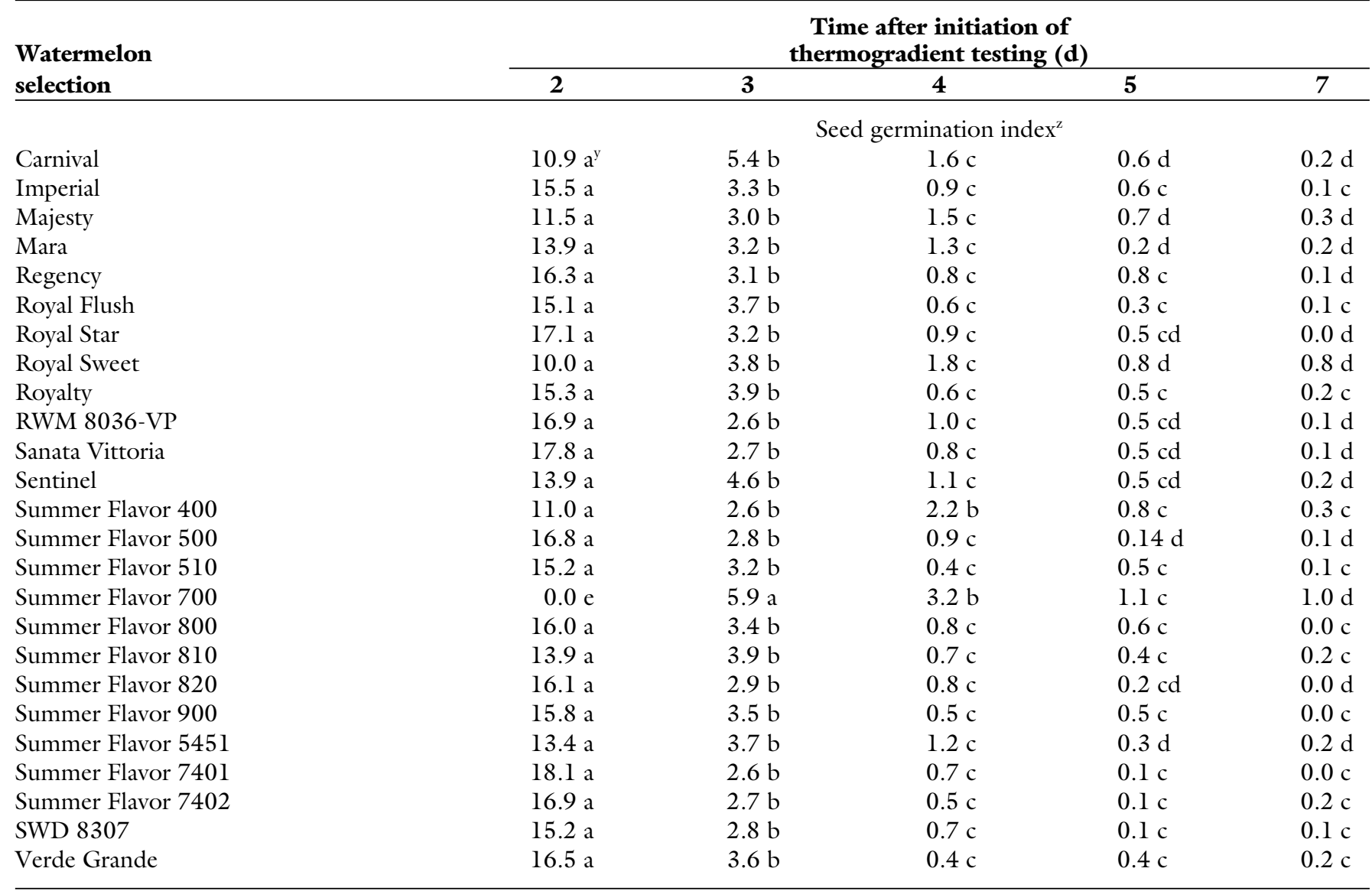

${ }^{\mathrm{z}}$ Germination index $=\sum$ (number of normal seedlings $) /($ days to first count $)+\ldots .+($ number of normal seedlings $) /($ days to final count $)$.

${ }^{y}$ Means within rows by LSD $(P=0.05)$. Data are means of three replications pooled over eight temperatures ranging from 62 to $94{ }^{\circ} \mathrm{F}\left(16.7\right.$ to $\left.34.4{ }^{\circ} \mathrm{C}\right)$. 
Table 4. Influence of temperature on seed germination percentage of diploid watermelon selections after 2 days on the thermogradient table.

\begin{tabular}{|c|c|c|c|c|c|c|c|c|c|}
\hline \multirow{2}{*}{$\begin{array}{l}\text { Watermelon } \\
\text { selection }\end{array}$} & \multicolumn{9}{|c|}{$\operatorname{Temp}\left({ }^{\circ} \mathbf{F}\right)^{\mathrm{z}}$} \\
\hline & 62 & 66 & 70 & 75 & 80 & 85 & 90 & 94 & Ideal range \\
\hline Summer Flavor 800 & $0.0 \mathrm{~d}$ & $2.7 \mathrm{~d}$ & $52.0 \mathrm{c}$ & 96.7 a & $98.0 \mathrm{a}$ & $96.0 \mathrm{a}$ & $96.7 \mathrm{a}$ & $71.3 \mathrm{~b}$ & $75-90$ \\
\hline Royal Star & $0.0 \mathrm{c}$ & $0.0 \mathrm{c}$ & $59.3 \mathrm{~b}$ & $96.7 \mathrm{a}$ & $100 \mathrm{a}$ & $99.3 \mathrm{a}$ & $100 \mathrm{a}$ & $92.0 \mathrm{a}$ & $75-94$ \\
\hline RWM 8036-VP & $0.0 \mathrm{c}$ & $1.3 \mathrm{c}$ & $79.3 \mathrm{~b}$ & $89.3 \mathrm{a}$ & $93.3 \mathrm{a}$ & $90.7 \mathrm{a}$ & $95.3 \mathrm{a}$ & $90.0 \mathrm{a}$ & $75-94$ \\
\hline Sanata Vittoria & $0.0 \mathrm{c}$ & $3.3 \mathrm{c}$ & $80.0 \mathrm{~b}$ & $90.7 \mathrm{ab}$ & $98.0 \mathrm{a}$ & $99.3 \mathrm{a}$ & 99.9 a & $97.3 \mathrm{a}$ & $75-94$ \\
\hline Summer Flavor 7401 & $0.0 \mathrm{c}$ & $4.0 \mathrm{c}$ & $84.0 \mathrm{~b}$ & $97.3 \mathrm{a}$ & $98.0 \mathrm{a}$ & $99.3 \mathrm{a}$ & $100 \mathrm{a}$ & $99.3 \mathrm{a}$ & $75-94$ \\
\hline Summer Flavor 7402 & $0.0 \mathrm{c}$ & $0.0 \mathrm{c}$ & $57.3 \mathrm{~b}$ & $88.0 \mathrm{a}$ & 96.7 a & $99.3 \mathrm{a}$ & $100 \mathrm{a}$ & $98.0 \mathrm{a}$ & $75-94$ \\
\hline Verde Grande & $0.0 \mathrm{c}$ & $0.0 \mathrm{c}$ & $37.3 \mathrm{~b}$ & $100 \mathrm{a}$ & $96.0 \mathrm{a}$ & $100 \mathrm{a}$ & $100 \mathrm{a}$ & $96.0 \mathrm{a}$ & $75-94$ \\
\hline Majesty & $0.0 \mathrm{~d}$ & $2.0 \mathrm{~d}$ & $20.0 \mathrm{c}$ & $52.0 \mathrm{~b}$ & $74.7 \mathrm{a}$ & $79.3 \mathrm{a}$ & $79.3 \mathrm{a}$ & $60.0 \mathrm{~b}$ & $80-90$ \\
\hline Mara & $0.0 \mathrm{~d}$ & $0.0 \mathrm{~d}$ & $42.0 \mathrm{c}$ & $73.3 \mathrm{~b}$ & $87.3 \mathrm{a}$ & $87.3 \mathrm{a}$ & $90.7 \mathrm{a}$ & $64.7 \mathrm{~b}$ & $80-90$ \\
\hline Imperial & $0.0 \mathrm{~d}$ & $6.0 \mathrm{~d}$ & $32.0 \mathrm{c}$ & $82.0 \mathrm{~b}$ & $95.3 \mathrm{a}$ & $94.0 \mathrm{a}$ & $97.3 \mathrm{a}$ & $89.3 \mathrm{ab}$ & $80-94$ \\
\hline Summer Flavor 820 & $0.0 \mathrm{~d}^{\mathrm{y}}$ & $2.0 \mathrm{~d}$ & $38.7 \mathrm{c}$ & $86.0 \mathrm{~b}$ & $92.0 \mathrm{ab}$ & $98.0 \mathrm{a}$ & $100 \mathrm{a}$ & $99.3 \mathrm{a}$ & $80-94$ \\
\hline Summer Flavor 900 & $0.0 \mathrm{~d}$ & $0.0 \mathrm{~d}$ & $24.7 \mathrm{c}$ & $86.0 \mathrm{~b}$ & $99.3 \mathrm{a}$ & $99.3 \mathrm{a}$ & $99.3 \mathrm{a}$ & $96.0 \mathrm{ab}$ & $80-94$ \\
\hline Summer Flavor 5451 & $0.0 \mathrm{c}$ & $1.0 \mathrm{c}$ & $1.0 \mathrm{c}$ & $78.7 \mathrm{~b}$ & $84.7 \mathrm{ab}$ & $87.3 \mathrm{a}$ & $87.3 \mathrm{a}$ & $91.3 \mathrm{a}$ & $80-94$ \\
\hline SWD 8307 & $0.0 \mathrm{~d}$ & $5.3 \mathrm{~d}$ & $45.3 \mathrm{c}$ & $78.0 \mathrm{~b}$ & $86.7 \mathrm{ab}$ & $86.0 \mathrm{ab}$ & $92.7 \mathrm{a}$ & $92.7 \mathrm{a}$ & $80-94$ \\
\hline Carnival & $0.0 \mathrm{~d}$ & $0.0 \mathrm{~d}$ & $10.0 \mathrm{~d}$ & $39.3 \mathrm{c}$ & $74.7 \mathrm{~b}$ & $89.3 \mathrm{a}$ & $85.3 \mathrm{ab}$ & $49.3 \mathrm{c}$ & $85-90$ \\
\hline Royal Sweet & $0.0 \mathrm{c}$ & $0.0 \mathrm{c}$ & $0.0 \mathrm{c}$ & $8.0 \mathrm{c}$ & $60.7 \mathrm{~b}$ & $86.0 \mathrm{a}$ & $93.3 \mathrm{a}$ & $72.0 \mathrm{~b}$ & $85-90$ \\
\hline Summer Flavor 810 & $0.0 \mathrm{e}$ & $2.0 \mathrm{e}$ & $42.0 \mathrm{~d}$ & $82.0 \mathrm{~b}$ & $66.0 \mathrm{c}$ & $94.0 \mathrm{a}$ & $94.7 \mathrm{a}$ & $64.0 \mathrm{c}$ & $85-90$ \\
\hline Summer Flavor 400 & $0.0 \mathrm{~d}$ & $0.0 \mathrm{~d}$ & $2.0 \mathrm{~d}$ & $30.7 \mathrm{c}$ & $66.0 \mathrm{~b}$ & $80.7 \mathrm{a}$ & $84.0 \mathrm{a}$ & $88.0 \mathrm{a}$ & $85-94$ \\
\hline Summer Flavor 700 & $0.0 \mathrm{c}$ & $0.0 \mathrm{c}$ & $0.0 \mathrm{c}$ & $0.0 \mathrm{c}$ & $12.7 \mathrm{~b}$ & $89.3 \mathrm{a}$ & $94.0 \mathrm{a}$ & $88.0 \mathrm{a}$ & $85-94$ \\
\hline
\end{tabular}

${ }^{\mathrm{z}}$ Temperature varied on thermogradient table as a standard deviation of about $\pm 2{ }^{\circ} \mathrm{F} ;{ }^{\circ} \mathrm{C}=5 / 9\left({ }^{\circ} \mathrm{F}-32\right)$.

${ }^{y}$ Means within rows by LSD $(P=0.05)$. Data are means of three replications.

plant, upon the appearance of a 0.1 to 0.2 inch ( 3 to $5 \mathrm{~mm}$ ) long radicle through the seed coat (Copeland and McDonald, 1995). After seeds germinated, they were removed from the dish and the germination index was calculated (Maguire, 1962).

All germination data were transformed by ARCSIN of square root then analyzed using analysis of variance (ANOVA). Our first statistical goal was to determine the minimum days needed to judge maximum germination vigor or index pooled over all temperatures (watermelon selection $\mathrm{x}$ time interaction). If the F-test was significant at $P=0.05$ for this interaction, the LSD at $P=0.05$ was derived to delineate the spread of time for which the germination index was maximum, for individual selections. After establishing the minimum days for maximum germination rate, our next statistical goal was to determine any differences in germination response of the selections to the various temperature ranges (selection $\times$ temperature interaction) on that day. If the Ftest was significant at $P=0.05$ for this interaction, the LSD at $P=0.05$ was derived to delineate the specific range of temperatures for which germination percentage was maximum for individual selections. Since only one lot of each selection was evaluated, we cannot determine from this research whether or not different lots of the same genotype would behave similarly than those reported here.

\section{Results and discussion}

Triploids. It was desirable to determine seed vigor information and also expedite the process and determine germination vigor in the least amount of time. Seeds of all selections, except 'Triple Star', uniformly germinated to their highest level within $2 \mathrm{~d}$ after initiation of thermogradient testing and, in fact, we found only small additional germination increments occurring up to the $7 \mathrm{~d}$ (Table 1 ). Before $2 \mathrm{~d}$, no visible signs of minimally acceptable radicle lengths were present. 'Triple Star' required $3 \mathrm{~d}$ to produce its highest germination rate, because the unusually large seed size may have slowed radicle protrusion. Therefore, delaying first data collection until $4 \mathrm{~d}$, as recommended by AOSA (1998) for simple germination testing, was too long to gather vigor information.

Watermelon selections interacted with temperature indicating subtle differences among watermelons in response to temperature (Table 2). 'Disko' germinated best after $2 \mathrm{~d}$ from 80 to $85^{\circ} \mathrm{F}$ with optimal germination for 'Summer Sweet 5244', 'Triple Crown' and 'Triple Star' from 80 to 90 'F. Only 'Triple Prize' had the narrowest temperature requirements, germinating best at only $85^{\circ} \mathrm{F}$ after $2 \mathrm{~d}$, with lower germination percentages at lower or higher temperatures. 'Rubita', 'Summer Sweet 2532', and 'Treasure Chest' required warmer temperatures of 85 to $90^{\circ} \mathrm{F}$ to germinate to their highest percentages after $2 \mathrm{~d}$. Because of very low seed vigor, 'Marita' and 'Summer Sweet 3521Y' had very low final germination percentages across all temperatures evaluated without any specific reliable optimum range.

Diploids. Similar to the triploids, we found that vigor could be determined in $2 \mathrm{~d}$ after initiation of thermogradient testing for all selections in our study, except 'Summer Flavor 700', which required $3 \mathrm{~d}$ (Table 
3 ). Before $2 \mathrm{~d}$, the radicles of germinating seeds had not reached minimum length. Germination of 'Summer Flavor 700' was probably delayed by unusually large seed size, requiring $3 \mathrm{~d}$ to produce a minimal length radicle. We suggest that a standard germination test for diploids can be successfully completed in $7 \mathrm{~d}$ rather than $14 \mathrm{~d}$ as suggested by AOSA (1998).

Temperature interacted with selection affecting germination percentage on the second day, indicating subtle differences in the optimum temperature to enhance the germination process (Table 4). Through LSD comparisons, germination responses were separated into six temperature range groups. Of all the selections evaluated, only 'Summer Flavor 800' germinated the same over the range of 75 to $90^{\circ} \mathrm{F}$. The most temperature versatile selections, 'Regency', 'Royal Star', 'RWM 8036-VP', 'Sanata Vittoria', 'Summer Flavor 500, 7401, 7402' and 'Verde Grande', germinated equally over almost a twenty-degree range from 75 to $94^{\circ} \mathrm{F}$. 'Majesty', and 'Mara' germinated best at 80 to $90^{\circ} \mathrm{F}$. 'Imperial', 'Royal Flush', 'Royalty', 'Sentinel', 'Summer Flavor 510, 820, 900, 5451', and 'SWD 8307' germinated fastest at the wider range of 80 to $94^{\circ} \mathrm{F}$. Conversely, 'Carnival', 'Royal Sweet', and 'Summer Flavor 810' required the narrowest temperature range of 85 to $90{ }^{\circ} \mathrm{F}$ for optimal germination, with lower germination at temperatures below or above this range. 'Summer Flavor 400 and 700' germinated best at 85 to $94^{\circ} \mathrm{F}$.

Temperature during the germination process plays a very significant role in the final watermelon plant stand in greenhouse or field. Triploid as well as diploid selections responded differently to temperature regimes, yet, in general, the most vigorous selections usually germinated at their highest rate at wider ranges of temperatures. Temperatures of $94^{\circ} \mathrm{F}$ inhibited germination of even the most vigorous triploid watermelons indicating that a critical maximum temperature was reached, agreeing with Vavrina and Maynard (1998).

For the most uniform germina- tion, a germination chamber, rather than a greenhouse bench, should be used since temperatures can be controlled more effectively. Our study suggests a variety of optimum temperature ranges for watermelon germination, yet commercially, it may be impractical or impossible for transplant growers to change germination room temperatures with different watermelon selections. Although triploid and diploid watermelon selections may have differed in the temperature ranges considered optimum for germination, all of the triploid and diploid selections germinated optimally at $85^{\circ} \mathrm{F}$ and at 85 to $90^{\circ} \mathrm{F}$, respectively, with these temperatures contained in the specific ranges reported above. AOSA (1998) recommends $86^{\circ} \mathrm{F}$ for watermelon germination testing and our study does not dispute this recommendation for either diploid or triploid selections. The temperature regime for triploids proposed by Vavrina and Maynard (1998) was valid for 8 out of 10 triploid selections evaluated in our study.

We suggest both vigor and final germination percentage information be included on seed packets for watermelons. Vigor data collection would take only 2 to $3 \mathrm{~d}$ at the optimum temperature recommended from thermogradient testing and provide more useful information to the transplant grower than the standard germination test required by the AOSA (1998).

Since only one lot of each watermelon selection was evaluated, we cannot determine in this research whether or not different lots of the same genotype would behave similarly to those lots tested in our study. Based on our findings, we found that the previously suggested optimal soil temperatures for diploid seed germination of 70 to $95^{\circ} \mathrm{F}$ (Harrington and Minges, 1954) are not applicable for all new diploid commercial selections. We recommend that germination at $85^{\circ} \mathrm{F}$ for triploids and 85 to $90^{\circ} \mathrm{F}$ for diploids may enhance total germination percentage of all watermelon selections and we suggest maintaining this germination temperature as consistently as possible across all users of the test.

\section{Literature cited}

Association of Official Seed Analysts. 1983. Part 1 Seed vigor- its meaning and application. Seed vigor testing handbook. AOSA, Lincoln, Nebr.

Association of Official Seed Analysts, 1998. Rules for testing seeds. AOSA, Lincoln, Nebr.

Copeland, L.O. and M.B. McDonald. 1995. Principles of seed science and technology. Chapman and Hall, New York.

Harrington, J.F. and P.A. Minges. 1954. Vegetable seed germination. Univ. Calif. Agr. Ext. Ser. Mimeo., Davis.

Kihara, H. 1951. Triploid watermelon. Proc. Amer. Soc. Hort. Sci. 58:217-230.

Maguire, J.D. 1962. Speed of germination aid in selection and evaluation for seedling emergence and vigor. Crop Sci. 2:176177.

Marr, C., W.J. Lamont, and M. Allison. 1991. Row covers improve seedless watermelon yields in an intensive vegetable production system. HortTechnology 1:103104.

Maynard, D.N. and G.W. Elmstrom. 1992. Triploid watermelon production practices and varieties. Acta Hort. 318:169-173.

Sachs, M. 1977. Priming of watermelon seeds for low-temperature germination. J. Amer. Soc. Hort. Sci. 102:175-178.

Simmonds, N. 1976. Evolution of crop plants. Longman Group Limited, New York.

Thompson H.C. and W.C. Kelly. 1957. Vegetable crops. McGraw-Hill, New York.

Vavrina, C.S. and D.N. Maynard. 1998. Production of triploid watermelon transplants, p. 300-303. In: J.D. McCreight (ed.). Cucurbitaceae '98. Pacific Grove, Calif.

Whitaker, T.W. and G.N. Davis. 1962. Cucurbits. Interscience, New York. 